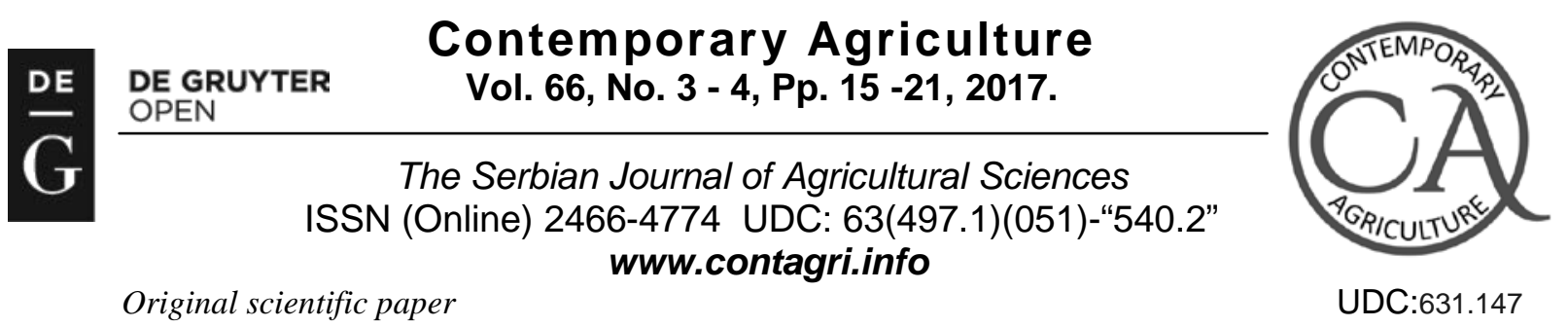

Original scientific paper

DOI:10.1515/contagri-2017-0014

\title{
EFFECT OF FERTILIZERS ON THE YIELD OF ALTERNATIVE SMALL GRAINS
}

\author{
Željko DOLIJANOVIĆ' ${ }^{1 \star}$, Dušan KOVAČEVIĆ' , Snežana OLJAČA ${ }^{1}$, \\ Svetlana ROLJEVIĆ NIKOLIĆ', Srđan ŠEREMEŠIĆ
}

\begin{abstract}
Summary: The purpose of this study is to evaluate the effect of organic farming technologies on the yield of alternative types of wheat: hard wheat (Triticum durum), spelt (Triticum aestivum ssp. spelta) and a common variety of (soft) winter wheat (Triticum aestivum ssp. vulgare). The experiment was carried out during 2010-11 and 2011-12, at the Radmilovac experimental field of the Faculty of Agriculture in Belgrade, according to the randomized block design in four replications. In addition to the control treatment (without fertilizers), microbiological fertilizers were applied in topdressing (alone) and in combination with organic fertilizer before sowing. Crops were grown under a four-crop rotation on leached chernozem in the rainfed water regime. The average yields of the varieties examined were not significantly different depending on the growing year, whereas fertilization showed a highly significant effect on the grain yield. The combined application of microbiological and organic fertilizers resulted in the highest yields in both years (5,209 and 4,992 $\mathrm{kg}$ ha-1, respectively). The selected wheat varieties exhibited different responses to the treatments applied. The highest yield was observed in the common soft wheat variety examined (5,170 and 5,611

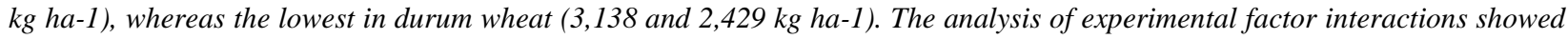
that statistically significant effects on the yield could be attributed to the year-fertilization interaction.

The wheat yields obtained are similar to those observed in the conventional production system due to favorable weather conditions and a proper selection of the type and sequence of crops that are part of the four-crop rotation (winter wheat, maize, spring barley + red clover, and red clover).
\end{abstract}

Key words: alternative small grains, fertilization, grain yield, organic farming

\section{INTRODUCTION}

Alternative crops are considered to be an underutilized group of crops, grown on small surfaces, having a specific purpose and potentially serving as an alternative source of dietary fibers and proteins. Organic agriculture and the production of healthy foods have been fueling the growth of interest in alternative small grains. Spelt (Triticum spelta) is one of the earliest domesticated types of wheat. It is suitable for cultivation in modest investment systems, harsh ecological conditions and marginal areas, without the use of pesticides (Ruegger and Winzeler, 1993). When cultivating in low-input conditions, the branch has a greater number of shoots per unit area, as well as higher shoot, whereas, by contrast, common wheat has a greater number of spikes per square meter, producing similar overall yields (Ruegger and Winzeler, 1993). With a good supply of nutrients to the soil, spelt produces lower yields compared to modern varieties of wheat. It is sensitive to lodging, not adapted to mechanical harvest (including additional grain peeling operations), and weeds make up 21-32\% of classes, which reduces spelt yields compared to common wheat (Escarnot et al., 2010). These disadvantages significantly decreased the cultivation of spelt in intensive agriculture in the past. However, the use of spelt in human nutrition has recently received a new and

\footnotetext{
${ }^{1}$ Željko Dolijanović $\mathrm{PhD}$, associate professor, ${ }^{1}$ Dušan KovačevićPhD, full professor, ${ }^{1}$ Snežana Oljača PhD, full professor, University of Belgrade, Faculty of Agriculture, Nemanjina 6, 11080, Beograd, Serbia,

${ }^{2}$ Svetlana Roljević NikolićPhD, research associate,Institute of Agricultural Economics, Volgina 15, 11060 Belgrade, Serbia,

${ }^{3}$ Srđan Šeremešić PhD, assistant professor, University of Novi Sad, Faculty of Agriculture, Trg Dositeja Obradovića 8, 21000 Novi Sad, Serbia,

•Corresponding author: Željko Dolijanović, e-mail: dolijan@agrif.bg.ac.rs, Tel: 011/4413321
} 
stronger emphasis as it is considered healthier and more natural compared to modern varieties of winter wheat. At present, spelt is primarily grown under rational investment conditions, meeting the organic food market demand.

Spelt has the potential for a variety of applications, depending on the genotype and processing conditions. In recent years, it has become increasingly important in the production of special types of bread, pasta and flakes due to a high nutritional value, favorable protein content, dietary fibers and mineral substances. An analysis of the spelt grain mineral composition indicated a higher content of phosphorus (about 10\%), copper (about 20\%), potassium (about 7\%), zinc (about 91\%), as well as iron and magnesium, compared to ordinary wheat (Ruibal-Mendieta et al., 2005). After common wheat (Triticum aestivum), hard wheat (Triticum durum) is the most widespread cultivated species of wheat. It is devoted to approximately 17 million hectares around the world, which represents about $8 \%$ of the total land devoted to wheat. The largest producers in the world are Turkey, Canada, the USA and Tunisia, whereas Italy, Greece and Spain are the leading producers of hard wheat in the European Union (FAO, 2014). Hard wheat is mainly used for preparing pasta, grits, noodles, as well as special types of breads. The favorable content of important microelements has increased the interest in using whole wheat grain products, as well as unique food products such as burghul, couscous, etc. The structure of the endosperm and the distribution of mineral matter in the grain contribute to the higher ash content in the hard wheat semolina (Denčić and Kobiljski, 2002). In low-input conditions, hard wheat yields are lower compared to conventional yields. However, Fagnano et al. (2012) argue that some varieties of hard wheat show a small loss of yield in the organic system of cultivation in relation to the average conventional yields. This is a consequence of a very poor reaction of old hard wheat varieties to favorable cultivation conditions, producing similar yields in optimal and high input conditions. Conversely, modern varieties indicate a good response to improvements in soil fertility and show a marked adaptation to the conditions of high input (De Vita et al., 2007). Labor productivity analyses of old wheat varieties in southern Italy have shown that there is a real possibility of cultivating hard wheat in marginal conditions, with insufficient moisture and nutrients in the soil, depending particularly on the genotype selection (Stagnari et al., 2008).

Soil fertility represents the basic determinant of productivity in each agricultural system (Watson et al., 2002). Organic production systems rely on organic matter management in order to maintain and increase the fertility of the soil, and thus optimize the production of crops. The supply of soil with organic matter is ensured by the introduction of crops, adding organic and microbiological fertilizers, passing plant residues, increasing the share of leguminous plants in the crop, fertilizing, cultivating cover crops, etc. However, nutrients in the form of organic matter are inaccessible to the plant, but due to the biological activity of the soil and chemical processes therein, they are transformed into easily accessible forms. Therefore, in organic agriculture, the presence of useful microorganisms is of key importance, due to the mineralization of organic matter and the fixation of atmospheric nitrogen. It is estimated that a link between wheat and diazotroph can provide 10-30 kg ha-1 and 10\% of the total wheat requirements for nitrogen (Kennedy et al., 2004). A large number of studies have been concerned with the effects of organic and microbiological fertilizers on soil fertility and crop productivity. Examining the effect of fertilization on the yield of alternative types of winter wheat in organic production, Kovačević et al. (2007) emphasize that the combination of biohumus and microbiological fertilizers contributed to a significantly higher yield (5.09 t ha-1) compared to using organic fertilizers (3.93 t ha-1). Dolijanović et al. (2014) indicate the importance of the combined application of organic and microbiological fertilizers in the organic production system, and conclude that combining the organic fertilization with biohumus and microbiological preparation in fertilization produce higher yields than in the practice of using only microbiological fertilizers. The purpose of this paper is to examine the differences in grain yield between alternative and common wheat varieties intended primarily to be grown in high input conditions, as well as the effects of organic and microbial fertilizers on the yield of organic wheat.

\section{MATERIAL AND METHODS}

The method used in this research is a randomized block system with four replications, and the surface of the elemental plot was $6 \mathrm{~m} 2$. The experiment was carried out at the Radmilovac (44o45'N, 20o35'E; Serbia) experimental school estate of the Faculty of Agriculture, University of Belgrade. The research was conducted during two seasons in the period 2010-11 and 2011-12. The research was carried out in field conditions in the luvic chernozem soil. The soil chemical properties were as follows: $\mathrm{pH}\left(\mathrm{H}_{2} \mathrm{O}\right)$ of 8.04, the total nitrogen content was $0.13 \%, \mathrm{P}_{2} \mathrm{O}_{5} 22.18 \mathrm{mg}$ per $100 \mathrm{~g}$ of soil, $\mathrm{K}_{2} \mathrm{O} 19.10 \mathrm{mg}$ per $100 \mathrm{~g}$ of soil, and the content of humus in the topsoil layer was $2.82 \%$. Different genotypes of winter wheat (of which three are so-called alternative grains, i.e. wheat varieties of different types of special purpose ('Dolap' and 'Nirvana')) and a baking soft wheat cultivar NS 40S, bred primarily for conventional intensive production, were enrolled in the study. The basic characteristics of the wheat genotypes used are as follows:

Durum, winter - spring durum wheat (Triticum durum), the genotype ‘Dolap’ is intended exclusively for making pasta, spaghetti, macaroni, etc. As it is a facultative cultivar, it can be sown from early October to mid - February. 
'Nirvana', a late variety of spelt wheat (Triticum spelta), is winter frost tolerant, with a booted grain. This genotype of wheat is used for making special bread that is digested much faster than those made from the regular wheat. NS 40S, a medium early baking genotype of common wheat (Triticum aestivum ssp. vulgare), is a leading cultivar in the conventional production in Serbia. It has good tolerance to winter frost, drought, high yield potential and the quality class is B1-B2. In addition to the control (C0), two experiments were conducted based on the varying factor C: C1 fertilization with a microbial inoculant - 5 l ha-1, "Slavol" (Bacillus megaterium 106 ml-1, Bacillus licheniformis 106 ml-1, Bacillus subtilis 106 ml-1, Azotobacter chroococcum 106 ml-1, Azotobacter vinelandii 106 ml-1, Derxia sp. $106 \mathrm{ml}-1$ ). The auxin activity corresponded to the activities of indole - 3 - acetic acid (IAA) in the range of $0.01-$ $0.1 \mathrm{mg}$ l-1. C2 - fertilization with biohumus and microbiological fertilizer during topdressing (3.0 t ha-1 + 5 l ha-1). Sowing was done at the end of the second week of October. In both planting years, the original seed of the Department for Small Grains, Institute of Field and Vegetable Crops in Novi Sad, were used. The experiment was conducted under a four-crop rotation that included a sequence of crops in the following order: maize - winter wheat spring barley + red clover - red clover, where legumes (red clover) served as a nitrogen source. The previous crop to winter wheat was maize. The grain yield was measured by elemental plots immediately after harvest and adjusted to a moisture level of $14 \%$. Samples were taken from a total of 10 plants in four replications in order to measure the productive characteristics of the plant (stem height, spike length, number of spikes, number of grains in spike, harvest index) and yield per hectare. The data analysis in all the trials was performed using the factorial analysis of variance. The data processing was carried out using the statistical package Statistica 6.0. The analysis of variance (the F-test) for the two-factorial trial and the significance of the treatment differences were tested by the LSD tests at a significance level of $\mathrm{p}<0.01$ and $\mathrm{p}<0.05$.

\section{Meteorological conditions}

In the first year of testing, the average air temperature was $11.5^{\circ} \mathrm{C}$. Lower air temperatures were recorded in October, December and March compared to the same months in the second experimental year. The air temperature in June was within the average for this month, enabling the timely filling of grains. The amount of rainfall in the first experimental year was $495 \mathrm{~mm}$, which is only $10 \mathrm{~mm}$ more compared to the second experimental year. Significantly higher precipitation was recorded in November, March, June and July in comparison with the same months in the second experimental year.

Table 1. The average monthly temperature and precipitation during the vegetation period (2010-11/2011-12)

\begin{tabular}{|l|l|l|l|l|l|l|l|l|l|l|l|}
\hline \multirow{2}{*}{ Year } & \multicolumn{9}{|l|}{ Temperature $\left({ }^{\circ} \mathrm{C}\right)$} & \multirow{2}{*}{ Average } \\
\cline { 2 - 12 } & X & XI & XII & I & II & III & IV & V & VI & VII & \\
\hline $2010-11$ & 10.5 & 12.2 & 2.5 & 2.0 & 1.4 & 8.2 & 14.6 & 17.3 & 22.4 & 24.1 & 11.5 \\
\hline $2011-12$ & 12.9 & 5.0 & 5.8 & 2.7 & -2.5 & 10.1 & 14.4 & 17.9 & 24.6 & 27.1 & 11.8 \\
\hline & \multicolumn{7}{|l|}{ Precipitation (mm) } \\
\hline
\end{tabular}

In the second year of study, the average air temperature $\left(11.8^{\circ} \mathrm{C}\right)$ was $0.3^{\circ} \mathrm{C}$ higher than in the first year, whereas the rainfall $(485 \mathrm{~mm})$ was below the perennial average. The amount of water deposits in the winter months of the second experimental year was satisfactory, which cannot be said for the beginning of the spring (March). However, more rainfall in April and May improved land moisture and allowed for further proper crop development. November, March, June and July were very dry. Extremely low air temperatures occurred in February, and extremely high in June and July.

\section{RESULTS AND DISCUSSION}

Successful production of cultivated plants depends, to a large extent, on agro-meteorological conditions, primarily the amount of precipitation and air temperature. These two factors define the climate of an area and significantly influence the growth and development of crops and weeds, as well as the effects of applied fertilizers and other cultural practices. The agro-meteorological conditions during the study were fairly uniform so that the average wheat yields obtained did not differ significantly from year to year.

The analysis of variance and the LSD test indicated that a selection of the winter wheat variety had a significant effect on the yield under organic production conditions. The grain yield of common soft wheat NS 40S (5,391 kg ha1) was statistically significantly higher compared to alternative types of wheat. In addition, highly significant 
differences were also found between alternative wheat varieties, whereby the spelt grain yield (4,954 kg ha-1) was higher than the hard wheat yield (2,784 kg ha-1). Fertilization treatments have shown a significant impact on wheat yields. With regard to the average values obtained, a more favorable effect on the wheat yield was recorded using the combined application of organic and microbiological fertilizer $(5,101 \mathrm{~kg}$ ha-1) compared to the sole use of microbiological fertilizers (4,307 kg ha-1) and the control yield (3,721 kg ha-1). In addition to the year-fertilization interaction, the interaction of other experimental factors had a statistically significant effect on the wheat grain yield. In both years of testing, the highest yield was recorded in the variety of common soft wheat (5,170 and 5,611 kg ha1) and the lowest in durum wheat (3,138 and 2,429 kg ha-1). Furthermore, significant differences in yield were recorded in the examined varieties of common and hard wheat, whereas the spelt varieties indicated no significant difference in yield. Although the year-fertilization interaction did not show a statistically significant impact on the yield, the combined effects of microbiological and organic fertilizers resulted in the highest yields in both years of testing (5,209 and 4,992 kg ha-1).

Table 2. Effects of the organic farming technology on the yield of alternative grains (kg ha-1)

\begin{tabular}{|c|c|c|c|c|c|c|}
\hline \multirow{2}{*}{$\begin{array}{c}\text { Year } \\
\text { A }\end{array}$} & \multirow{2}{*}{$\begin{array}{c}\text { Alternative small grains } \\
\text { B }\end{array}$} & \multicolumn{3}{|c|}{$\begin{array}{c}\text { Fertilizer } \\
\text { C }\end{array}$} & \multicolumn{2}{|c|}{ Average } \\
\hline & & $\mathrm{C}_{0}$ & $\mathrm{C}_{1}$ & $\mathrm{C}_{2}$ & $\mathrm{AB}$ & A \\
\hline \multirow{4}{*}{ 2010/11 } & T. aestivum ssp. vulgare - NS 40S & 4264 & 5575 & 5671 & 5170 & \multirow{3}{*}{4385} \\
\hline & Triticum durum - Dolap & 2213 & 2882 & 4321 & 3138 & \\
\hline & Triticum spelta - Nirvana & 4002 & 4899 & 5636 & 4846 & \\
\hline & AC & 3493 & 4452 & 5209 & & \\
\hline \multirow{4}{*}{ 2011/12 } & T. aestivum ssp. vulgare - NS 40S & 4951 & 5342 & 6542 & 5611 & \multirow{3}{*}{4367} \\
\hline & Triticum durum - Dolap & 2145 & 2275 & 2867 & 2429 & \\
\hline & Triticum spelta - Nirvana & 4752 & 4867 & 5567 & 5062 & \\
\hline & AC & 3949 & 4161 & 4992 & & \\
\hline \multirow{4}{*}{$\mathrm{BC}$} & T. aestivum ssp. vulgare - NS 40S & 4608 & 5459 & 6107 & 5391 & \multirow{3}{*}{$\mathrm{B}$} \\
\hline & Triticum durum - Dolap & 2179 & 2579 & 3594 & 2784 & \\
\hline & Triticum spelta - Nirvana & 4377 & 4883 & 5602 & 4954 & \\
\hline & C & 3721 & 4307 & 5101 & & \\
\hline
\end{tabular}

\begin{tabular}{|c|c|c|c|c|c|}
\hline LSD & 0.05 & 0.01 & & 0.05 & 0.01 \\
\hline $\mathrm{A}$ & 210 & 359 & $\mathrm{AB}$ & 364 & 622 \\
\hline $\mathrm{B}$ & 257 & 440 & $\mathrm{AC}$ & 364 & 622 \\
\hline $\mathrm{C}$ & 257 & 440 & $\mathrm{BC}$ & 446 & 762 \\
\hline & & & $\mathrm{ABC}$ & 630 & 1078 \\
\hline
\end{tabular}

The application of different fertilizers contributed to a significant increase in average yields. The results obtained indicate a fairly uniform effect of the independent application of microbiological fertilizers on the yield of the tested varieties ranging from $11.6 \%$ ('Nirvana') to $18.5 \%$ (NS 40S) compared to the control yield. Conversely, there were more significant differences in yields in relation to the control yield when using the combined fertilizer application (ranging from 28\% ('Nirvana') to 65\% ('Dolap’)). The average grain yield in organic farming varies considerably under the influence of agro-metrological factors, varieties, as well as the application of fertilizers (ABC interactions). In the first experimental year, the application of the studied fertilizers influenced significantly the yield increase in all three wheat varieties. However, in the second experimental year, statistically significant yield results were achieved only using the combined application of organic and microbiological fertilizers.

The main problem in low-input systems is the supply of nutrients to plants. Optimum amounts of nutrients in organic agriculture are provided by the most commonly used alternative methods, which include the addition of natural mineral fertilizers, plant residues, use of legumes, green manure and the use of soil microorganisms in the form of microbiological fertilizers. The application of organic fertilizers could improve the physical and chemical properties of the soil rhizosphere (Shepherd et al., 2002), and contribute to an increase in biomass and microorganism activity (Chang et al., 2007), which results in the increase in crop yields. The results of these studies have shown that the gradual release of nutrients from organic fertilizers with foliar topdressing in spring (C2) contributed to the better 
absorption of available nutrients and the production of a significantly higher grain yield (5121 kg ha-1) compared to Experiments C1 (18.4\%) and C0 (37.1\%). Furthermore, a highly significant increase in yield was found in the experiment with a self-contained application of microbiological fertilizers in relation to the control (15.7\%). Mohammed et al. (2012) emphasize that the integrated application of organic fertilizers and effective microorganisms affects the increase in the wheat shoot height, the number of fertile shoots, the number of seeds in the spike and the thousand kernel weight. The suitability of the integral application of organic and microbiological fertilizers is explained by the balanced and gradual release of nutrients, better adoption by the plant and by improving the water capacity. The effects of the use of organic and microbiological fertilizers in the organic production of wheat were examined by other authors (Dolijanović et al., 2014, Kovačević et al., 2007).

The selection of variety is a very important factor for achieving positive results in organic production. Due to the breeding process, modern cereal varieties are more efficient in nitrogen use under conventional production conditions compared to old varieties (Konvalina, 2009). However, studies have shown that modern varieties exhibit greater efficiency even in conventional low-input systems. By examining the response of a twenty-year-old wheat cultivar to a low use of mineral fertilizers, El Bassam (1998) concluded that modern varieties have a higher yield potential than old varieties, even in low-investment conditions. According to Kovačević et al. (2009) the conventional wheat variety NS 40S produced a significantly higher yield compared to the yield of alternative cereals in the organic farming system. Similar results were obtained in this study. Namely, the average grain yields of conventional varieties of common wheat (5,170 and 5,611 kg ha-1) were significantly higher compared to the yields of spelt varieties (4,846 and 5,062 kg ha-1) and hard wheat (3,138 and 2,429 kg ha-1), in both experimental year. Konvalina et al. (2009) argues that a higher efficiency of the adoption and use of nitrogen by modern varieties is caused by a more efficient use of the absorbed nutrients in the plant, and not by the higher absorption capacity of the root system. Guarda et al. (2004) concludes that in low-input conditions, the best results are obtained by cultivating modern varieties since they have qualities that enable them to produce good yields even in low nitrogen availability conditions. The lowest average yield was obtained in the hard wheat variety 'Dolap' (2,784 kg ha-1). Stanković (2003) states that the yield of winter hard wheat depends, to a large extent, on the resistance of the variety to low temperatures, which can account for the significantly lower yield of hard wheat, especially in the second experimental year. Studies have shown that the efficiency of the use of nutrients and water in hard wheat can be increased by selecting varieties compatible with useful microorganisms (Singh et al., 2012). The yield of cultivar varieties (4,954 kg ha-1) was significantly lower than the yield of conventional common wheat variety (5,391 kg ha1). These results are consistent with the findings of Kovačević et al. (2009) reporting a significantly higher yield of the conventional variety of common wheat NS 40S (5.32 t ha-1) compared to the 'Nirvana' cultivar (4.78 t ha-1). Conversely, yield stability is one of the most desirable features of a genotype for wide cultivation. Analyzing the productivity of alternative cereals in organic farming, Roljević (2014) suggests that the yields of alternative cereals are lower, but more stable compared to the variety selected for high-input conditions.

\section{CONCLUSION}

The availability of sufficient amounts of nutrients is a key factor for plant growth and yield in the organic production system. The results obtained indicate that the application of organic and microbiological fertilizers is of paramount importance to producing optimal crop yields. The sole application of microbiological fertilizers exerted a positive effect on the average yield of wheat relative to the control yield. However, the combined application of organic and microbiological fertilizers exerted twofold favorable effects on the wheat yields obtained.

When regard to wheat yields in low-input conditions, the highest yield was recorded in a conventional wheat variety, whereas the yield of alternative wheat varieties was significantly lower.

On the basis of the results obtained, it can be concluded that the management of soil fertility and the selection of crop species play a key role in yield production and stability in the organic production system.

\section{ACKNOWLEDGEMENT}

This research was supported by the Ministry of Education, Science and Technological Development of the Republic of Serbia (project grants No.TR31066 and III 46006) 


\section{REFERENCES}

CHANG EH, CHUNG RS, TSAI YH: Effect of different application rates of organic fertilizer on soil enzyme activity and microbial population. Soil Science and Plant Nutrition, 53(2)132-140, 2007.

DE VITA P, MASTRANGELO AM, CODIANNI P, FORNARA M, PALUMBO M, CATTIVELLI L: Bio-agronomic Evaluation of Old and Modern Wheat, Spelt and Emmer Genotypes for Low-input Farming in Mediterranean Environment. Ital. J. Agron. / Riv. Agron., 3, 291-302, 2007.

DENČIĆ S, KOBILJSKI B: Mogućnosti i potencijali durum pšenica u Jugoslaviji. "Zbornik radova", 36, 219-228, 2002.

DOLIJANOVIĆ Ž, OLJAČA S, KOVAČEVIĆ D, ĐORĐEVIĆ S, ROLJEVIĆ S: Prinos zrna krupnika (Triticum aestivum ssp. spelta) u zavisnosti od lokaliteta gajenja. Zbornik naučnih radova sa XXVIII Savetovanja agronoma, veterinara, tehnologa i agroekonomista, 20(1-4)65-73, 2014.

EL BASSAM N: A concept of selection for 'low input' wheat varieties. Euphytica, 100(1)95-100, 1998.

ESCARNOT E, AGNEESSENS R, WATHELET B, PAQUOT M: Quantitative and qualitative study of spelt and wheat fibres in varying milling fractions. Food Chemistry, 122,857-863, 2010.

FAGNANO M, RITIENI A, FIORENTINO N, FERRACANE R, GRAZIA D'EGIDIO M, RAIMONDI G: Durum Wheat in Conventional and Organic Farming: Yield Amount and Pasta Quality in Southern Italy. The Scientific World Journal Volume 2012, Article ID 973058, 9 pages, 2012.

GUARDA G, PADOVAN S, DELOGU G: Grain yield, nitrogen-use efficiency and baking quality of old and modern Italian bread-wheat cultivars grown at different nitrogen levels. Europ. J. Agronomy, 21, 181-192, 2004.

KENNEDY IR, CHOUDHURY ATMA, KECSKÉS ML: Non-symbiotic bacterial diazotrophs in crop-farming systems: can their potential for plant growth promotion be better exploited?. Soil Biology and Biochemistry, 36(8)1229-1244, 2004.

KONVALINA P, STEHNO Z, MOUDRÝ J: The Critical Point of Conventionally Bred Soft Wheat Varieties in Organic Farming Systems. Agronomy Research, 7, 801-810, 2009.

KOVAČEVIĆ D, DOLIJANOVIĆ Ž, OLJAČA S, MILIĆ V: Organska proizvodnja alternativnih vrsta ozime pšenice, Poljoprivredna tehnika, 32(4) 39-46, 2007.

KOVAČEVIĆ D, DOLIJANOVIĆ Ž, OLJAČA S, MILIĆ V: Prinos nekih alternativnih vrsta pšenice u organskoj proizvodnji. Journal of Scientific Agricultural Research, 70(3)17-25, 2009.

MOHAMMED SS, OSMAN AG, MOHAMMED AM, ABDALLA AS, SHERIF AM, RUGHEIM A ME: Effects of organic and microbial fertilization on wheat growth and yield. Int. Res. J. Agric. Sci. Soil Sci., 2, 149-154, 2012.

ROLJEVIĆ S: Produktivnost alternativnih strnih žita u sistemu organske zemljoradnje. Doktorska disertacija, Poljoprivredni fakultet, Univerzitet u Beogradu, 2014.

RUEGGER A, WINZELER H: Performance of Spelt (Triticum spelta L.) and Wheat (Triticum aestivum L.) at two Different Seeding Rates and Nitrogen Levels under Contrasting Environmental Conditions. J. Agronomy \& Crop Science, 170, 289—295, 1993.

RUIBAL-MENDIETA NL, DELACROIX DL, MIGNOLET E, PYCKE J, MARQUES C, ROZENBERG R, PETITJEAN G, HABIB-JIWAN J, MEURENS M, QUETIN-LECLERCQ J, DELZENNE MN, LARONDELLE Y: Spelt (Triticum aestivum ssp. spelta) as a source of bread making flours and bran naturally enriched in oleic acid and minerals but not phytic acid. Journal of Agricultural and Food Chemistry, 53(7)2751-2759, 2005.

SHEPHERD MA, HARRISON R, WEBB J: Managing soil organic matter - implications for soil structure on organic farms. Soil Use and Management, 18(S1)284-292, 2002.

SINGH AK, HAMEL C, DEPAUW RM, KNOX RE: Genetic variability in arbuscular mycorrhizal fungi compatibility supports the selection of durum wheat genotypes for enhancing soil ecological services and cropping systems in Canada. Canadian Journal of microbiology, 58(3)293-302, 2012.

STAGNARI F, CODIANNI P, PISANTE M: Agronomic and Kernel Quality of Ancient Wheats Grown in Central and Southern Italy. Cereal Research Communications, 36(2)313-326, 2008.

STANKOVIĆ L: Produktivno bokorenje kod sorti tvrde pšenice - Triticum durum Desf. Zbornik radova Instituta za ratarstvo i povrtarstvo, 38, 157-161, 2003.

WATSON CA, ATKINSON D, GOSLING P, JACKSON LR, RAYNS FW: Managing soil fertility in organic farming systems. Soil Use and Management, 18(S1)239-247, 2002.

Food and Agriculture Organization of the United Nations, available at: http://faostat.fao.org/site/339/default.aspx 


\title{
UTICAJ ĐUBRIVA NA PRINOS ALTERNATIVNIH ŽITA
}

\author{
Željko DOLIJANOVIĆ , Dušan KOVAČEVIĆ, Snežana OLJAČA, Svetlana ROLJEVIĆ NIKOLIĆ, \\ Srđan ŠEREMEŠIĆ
}

Rezime. Izvod: Cilj ispitivanja jeste ocena uticaja organske tehnologije gajenja na prinos zrna alternativnih vrsta pšenice: tvrde pšenice (Triticum durum), krupnika (Triticum aestivum ssp. spelta) i jedne sorte obične ozime pšenice (Triticum aestivum ssp. vulgare). Eksperimenti su izvedeni tokom 2010/11 i 2011/12 godine na „Radmilovcu“, oglednom dobru Poljoprivrednog fakulteta u Beogradu, po metodi slučajnog blok sistema u četiri ponavljanja. Pored kontrolne varijante (bez primene đubriva), primenjeno je mikrobiološko đubrivo u prihranjivanju (samostalno) i u kombinaciji sa organskim đubrivom koje je primenjeno u jesen pred setvu. Usevi su gajeni u okviru četvoropoljnog plodoreda na zemljištu tipa izluženi černozem u prirodnom vodnom režimu.

Prosečni prinosi zrna ispitivanih vrsta nisu se statistički značajno razlikovali u zavisnosti od godine ispitivanja, dok su tretmani đubrenja pokazali statistički vrlo značajan uticaj na prinos. Kombinovanom primenom mikrobiološkog i organskog đubriva dobijeni su najviši prinosi u obe godine ispitivanja (5209 i 4992 kg ha-1). Kada su pitanju ispitivane vrste žita, u obe godine ispitivanja najveći prinos je ustanovljen kod sorte obične, meke pšenice (5170 i 5611 kg ha-1), a najmanji kod tvrde pšenice (3138 i 2429 kg ha-1). Interakcije ispitivanih faktora, osim interakcije godina-đubrenje, su imale statistički značajan uticaj na prinos zrna ispitivanih vrsta.

Dobijeni prinosi zrna ispitivanih vrsta su na nivou prinosa konvencionalne proizvodnje prvenstveno zbog povoljnih meteoroloških uslova u godinama ispitivanja i pravilnog izbora vrsta i redosleda useva koji ulaze u sastav četvoropoljnog plodoreda (ozima pšenica, kukuruz, jari ječam+crvena detelina i crvena detelina).

Ključne reči: alternativna žita, đubrenje, organska poljoprivreda, prinos zrna

\section{Received / Primljen: 06.07.2017.} Accepted / Prihvaćen: 23.12.2017. 